\title{
Analysis of Teaching Based on Learning in the Context of the European Space of Higher Education
}

\author{
María Teresa García-Álvarez, Rosa María Mariz- \\ Pérez University of Coruna, Spain
}

\begin{abstract}
Bologna Declaration entails important changes for University Education. The establishment of a system of credits involves a more active and dynamic role to be adopted by students. Besides, it entails a new planning of subjects where the necessity of establishing a professional academic profile of the degree is placed on the definition of the competence units and the design of a module of formation are required. In this paper, we show the planning process of a subject of the degree in Business at University of Coruna (Spain) in the framework of the European Space of Higher Education. The obtained results have been, in general, satisfactory from point view of students and professors.
\end{abstract}

\section{Introduction}

We are merged in a context of reconsideration of the university functions in the society. There are many causes that motive these changes [1]:

- Survival. The flexible organizations are the only companies that can have hope in surviving and having success.

- Necessity of compatibility, comparability and competitiveness in the European higher education.

- The new technologies. With the development of these technologies, the objective of higher teaching is favouring and stimulating the rigor in the information selection, promoting the rational organization of that information and supporting their possible interpretation.

In this context, the Bologna Declaration (June, 1999) entails the convergence beginning of the structure in the European education systems. It seeks to promote the following objectives:

1. Adoption of a system of degrees that allows to promote the competitiveness of the European system of higher education [2].

2. The introduction of a system based on two main cycles [3].

3. Development of the European Credit Transfer System with the aim of favouring the student mobility [4].
4. Promotion of the elimination of the obstacles which do not allow for the mobility of students, professors and administrative staff [5].

5. Implementation of the necessary European dimensions of the higher education space, particularly with regard to curricular contents, inter-institutional co-operation and integrated programmes of study, training, and research [6].

Besides, the European Space of Higher Education entails the establishment of a higher importance of learning. Traditionally, the emphasis of the higher education was given to teaching. However, nowadays, active and motivating teaching methodologies are being used. They suppose a greater autonomy and academic responsibility of students [7]. There are various methods, such as academic works, study of cases, practical or tutorial classes. These elements are basic in order to obtain the competences that the degree entails. Competences are defined as "a combination of knowledge, abilities (intellectual, manual, social, ect.), attitudes and values which will allow students to resolve problems adequately or their intervention in questions of a certain academic, professional or social context [8].

\section{The importance of learning in the new university context}

Traditionally, the emphasis of teaching was placed on master lessons. However, given the characteristics established by the European Space of Higher Education, special emphasis is on the learning process. Therefore, it is necessary an approach more focused on student [9]

With the aim of favouring this change, an intrinsic and extrinsic motivation is required in professors and students. The internal reasons are given by personal and social factors associated to the action of learning. Besides, the external reasons are driven by the institutional rewards towards good teaching and learning in the lecture room [10].

These characteristics establish the necessity of developing a new role, in the case of professors, which allows preparing new methodologies that favour the 
learning of students. Therefore, professors have to undertake new tasks, such as:

- A widening of the traditional functions where, besides of the development of the master class, various activities are required based on the advice of students, the development and supervision of learning activities or the teaching coordination [11].

- The need to develop the significance of teaching beyond its private sense, which leads to individualism [12].

In this context, universities have promoted various actions with the aim of reaching that objective. In the case of Coruna University, where we have developed our paper, various actions have been initiated in the academic course 2004/2005-such as the creation of the Quality Departamental Groups. The main objective of these groups has been to advance towards the subject conversion to the European Credit System. Therefore, it was necessary to elaborate the teaching guides which could show the basic pedagogical concepts for the obtaining of the competences previously established.

These activities have supposed the beginning of the experience in teaching innovation with the aim of carrying out the requirements of the Bologna Declaration. In this context, the objective is to adapt the teaching methodology with the aim of promoting more active learning from students, to develop the established competences in the teaching planning and to create a feedback system that allows to evaluate and to explain the results obtained.

Therefore, a series of innovations have been made in the subjects by means of the implementation of active methodologies (learning based on case studies, assisted learning techniques or cooperative work). Likewise, a suitable evaluation system to the teachinglearning process (a continual evaluation is necessary in the new environment) has been developed.

The objective of this paper is to analyze the effects of these changes in higher education. We study the case of a subject in our Business Degree. In this sense, we show its planning process in the new context of the European Space of Higher Education. The identification of the competences, the design of the formation module and the establishment of the evaluation method are required. Likewise, we establish the different active teaching methodologies that we have applied and their main advantages and limitations. Finally, we show the assessment of our experience in teaching innovation from student and professor view points.

\section{Adaptation of a subject of Business degree in the framework of the European Space of Higher Education}

From the characteristics of the European Space of Higher Education, commented before, a higher importance of learning in the higher education should be established.

In this paper, we show the planning process that we have developed with the aim of adapting the subject "Economy of the Enterprise: Management and Organization" to the European Space of Higher Education. It is a four- monthly subject which is studied in the first course of the degree in Business at Coruna University (Spain).

In this context, we show the planning process of this subject in the new context of higher education. Therefore, we establish a) the professional academic profile of the degree, b) the identification of the specific competences in the analyzed subject and b) the design of the formation module where the list of topics, the characteristics of the active teaching and the evaluation system are defined.

\subsection{Establishment of the professional academic profile of the degree.}

The main professional academic competence of the degree in Business Management is the introduction of the necessary knowledge to create new executives. So, it is necessary to develop knowledge related with the decision process in the different levels of the enterprise: Finances, Accounting, Marketing.

\subsection{Identification of the competences}

1. Establishment of the first competence: students should identify the relevant factors for the development of the strategy and managerial objectives. 2. Establishment of the second competence: students should identify the most suitable organizational structure for companies taking into account their characteristics.

\subsection{Design of the formation module}

The design of the formation module is given by the development of three phases:

1) Elaboration of the list of topics.

2) The design of the teaching process.

3) The establishment of the evaluation method.

\subsubsection{Elaboration of the list of topics}

Table 1 shows the list of topics of the analyzed subject. 
We can observe that topics are divided in two types which coincide with the name of the subject: management and organization.

The analysis of the management topics allows obtaining the first competence. Likewise, the study of the organization topics allows reaching the second competence, established above.

Table 1. List of topics of the analyzed subject in Business Degree

\begin{tabular}{|c|l|}
\hline \multicolumn{2}{|c|}{$\begin{array}{l}\text { Economy of the Enterprise: Management and } \\
\text { Organization }\end{array}$} \\
\hline \multirow{2}{*}{\begin{tabular}{c}
\multicolumn{1}{|c|}{ Topic } \\
\hline Management
\end{tabular}} & $\begin{array}{l}\text { 1. Economic analysis of the } \\
\text { enterprise. } \\
\text { 2. Industrial analysis versus } \\
\text { resources and capacities theory. } \\
\text { 3. Business strategy } \\
\text { 4. Management objectives }\end{array}$ \\
\hline $\begin{array}{c}\text { II. } \\
\text { Organization }\end{array}$ & $\begin{array}{l}\text { 5. Introduction of organizational } \\
\text { analysis. } \\
\text { 6. Parameters of organizational } \\
\text { design. } \\
\text { 7. Contingency factors. } \\
\text { 8. Organizational models }\end{array}$ \\
\hline
\end{tabular}

Source: Own elaboration

\subsubsection{The design of the teaching process}

The teaching process is developed by means of the consecution of the activities which are shown in Figure 1.

ECONOMY OF THE ENTERPRISE: MANAGEMENT AND ORGANIZATION

THEORY AND PRACTICE TEACHING

OTHER TEACHING ACTIVITIES: ACADEMIC WORKS

PERSONAL STUDY OF THE STUDENTS

Source: Own elaboration

Figure 1. Application of the European Space of Higher Education to a subject of Business Degree

Now, we establish a detailed description of these activities:

1. Theoretical and practical teaching.

In the case of the theoretical teaching (master class) is characterized by following these objectives: a) the acquisition of organized information from various documentary sources which have a difficult access for students, b) the promotion of the understanding and application of the specific procedures of the subject and c) the seeking of interest and motivation of students towards the subject.

However, the use of this teaching methodology entails, from the view point of students and professors, some positive and negative aspects which are shown in Table 2 and Table 3.

Table 2. Advantages and limitations of master class from professor view point

\begin{tabular}{|c|c|}
\hline & Professors \\
\hline $\begin{array}{c}\text { Positive } \\
\text { aspects }\end{array}$ & $\begin{array}{l}\text { - Intellectual challenge in the } \\
\text { structuring of master lesson. } \\
\text { - It allows to awake the interest in the } \\
\text { subject. } \\
\text { - Personal satisfaction when a good } \\
\text { master lesson is given. }\end{array}$ \\
\hline $\begin{array}{c}\text { Negative } \\
\text { aspects }\end{array}$ & $\begin{array}{l}\text { - Passive role of students. } \\
\text { - Overcrowding. } \\
\text { - Explication of topics that can not be } \\
\text { attractive. }\end{array}$ \\
\hline
\end{tabular}

Source: [13]

Table 3. Advantages and limitations of master class from student view point

\begin{tabular}{|c|c|}
\hline & Students \\
\hline $\begin{array}{c}\text { Positive } \\
\text { aspects }\end{array}$ & $\begin{array}{l}\text { - It stimulates the interest for the } \\
\text { subject. } \\
\text { - It entails a structured and clear } \\
\text { explanation. } \\
\text { - If the preparation is suitable and the } \\
\text { content has interest. }\end{array}$ \\
\hline $\begin{array}{c}\text { Negative } \\
\text { aspects }\end{array}$ & $\begin{array}{l}\text { - Difficulty of understanding. } \\
\text { - Bad use of audiovisual aids. } \\
\text { - Unsuitable difficulty level. }\end{array}$ \\
\hline
\end{tabular}

Source: [13]

The use of the master classes has the following characteristics:

- Clear presentation of the problem that will be analyzed and of the theories and available technical instruments for its study.

- Development of the capacity of critical analysis by means of an interdisciplinary approach.

- Establishment of the empirical information sources.

- Reflection of the practical applicability about the studied topics.

- Development of participative and dynamic classes.

Besides, the master class, it is also important to introduce practical classes. At the end of every topic, students will have to resolve a case study of a real enterprise where they will have to apply knowledge acquired in the master class. This methodology favours the obtaining of competences in students based on critical awareness, the oral and writing expression or the capacity of working in group. Therefore, the student is 
the main actor of his learning process by means of the execution of different activities: investigation, analysis, presentation and discussion of the conclusions.

However, the application of this teaching methodology also entails some advantages and problems.

The main advantages are given by the following characteristics:

- Development of significant learning by students [14].

- This methodology promotes the development of the critical judgment of students [15].

- It stimulates the motivation of students because this methodology is based on real cases. Students could find these situations in their professional practice [14].

- Development of communication skills [15].

However, this methodology has too some limitations such as:

- This methodology is difficult to adequately establish in large groups [14].

- Difficulty of professors to plan and design the practical cases which allow students to be motivated [16].

- Non existence of an only solution. Therefore, it is necessary to deal with all solutions considered by students and those solutions which are not been obtained by them [14].

2. Besides, other teaching activities will be performed. In this context, students have to conclude academic work during the course in groups of three people. They have to follow the next phases:

- Analysis of a strategic/organizational problem with theory and practical relevance which will be chosen from economic press.

- Students will choose the theory approach and the available bibliographic sources.

- Students will choose the most methodology to be applied.

- Drawing-up of the work.

- Presentation of the work in class.

This active teaching methodology allows the establishment of a study guide that shows the objectives, the necessary documental sources for the study and, therefore, the learning that students have to obtain after the execution of this work.

This methodology has too, as the previous teaching activities, some advantages and limitations.

The main advantages are given by the following characteristics [14]:

- It favours the relation professor-student.

- This methodology promotes the student activity.

- It helps students with their beginning in the development of creative flairs.

- This methodology promotes the development of responsibility in students in their work.

- It favours the continual evaluation by teacher and the self-appraisal of student.
With regard to the limitations, it is emphasized that:

- This methodology entails a change in students (an active role).

- Attitude and this is not always an easy task.

- The learning rhythm is lower than, for example, with the exposing technique.

- This methodology calls for more technical preparation by professor.

- It can increase the differences within the group because each student has his rhythm.

- This methodology demands a monitoring by professor.

3. Personal study of the student. In the framework of the European Space of Higher Education, some theory hours will be replaced with tutorials. In those hours, professors will supervise the academic works and students could resolve questions related with the development of them.

\subsubsection{Establishment of the evaluation method}

Finally, the application of this new teaching model will mean changes in the evaluation method as well (see Table 4).

The final grade of the subject will be given by the exam and the teaching spaces derived from the European credits.

Therefore, students have to participate in the European teaching space to pass the subject. So, it is necessary for students to adopt a more dynamic role.

Table 4. Breakdown of the final grade in the analyzed subject in Business Degree

\begin{tabular}{|c|c|c|}
\hline Concept & $\begin{array}{c}\text { Maximum } \\
\text { points }\end{array}$ & $\begin{array}{c}\text { Minimum } \\
\text { required } \\
\text { points }\end{array}$ \\
\hline $\begin{array}{c}\text { Attendance at } \\
\text { class }\end{array}$ & 1 point & $\begin{array}{c}1,5 \text { points for } \\
\text { both concepts }\end{array}$ \\
\hline Academic work & 3 points & \\
\hline Examination & 6 points & 2,5 points \\
\hline
\end{tabular}

Source: Own elaboration

\section{Advantages and limitations of the teaching based on learning}

The application of the new teaching methodology based on learning has supposed some advantages and 
problems from the view point of the students and professors.

Students indicate the following positive aspects:

- The acquisition of competences related with the development of communicative skills, the learning by themselves and the necessity of adopting a more active role because they will have to use it in the enterprise.

- The execution of practice cases based on real enterprises related with the topic analyzed in class.

- The guide of the professor in the use of books and other references to conclude the academic works.

- The supervision of the academic work with tutorials.

With respect to the weak points of the new teaching method, students establish:

- The difficulties to manage the different implication levels of the group members that make the academic work.

- The fear of expressing themselves unsuitably in the work presentation.

- A student group does not like the new teaching methodology based on learning because they prefer a more passive role.

Professors obtain as positive aspects:

- The advantage of having more information to shape the final grade of the subject.

- The new teaching methodology entails a closer relation professor-student and the consequent positive aspects -higher trust, a friendly atmosphere in class.

In relation with the weak points of the new teaching method, professors establish:

- Higher work levels which are not occasional but constant.

- Difficulties to know if work is achieved by the group or if it is result of an individual task distribution between the group members.

\section{Conclusions}

In this paper, we have summarized our pedagogical experience in the planning and application of new teaching methodologies in the subject "Economy of the enterprise: management and organization". This subject belongs to the degree of Business, first course, at University of Coruna (Spain).

The objectives and competences are obtained by means of the application of a new teaching model where there is a more dynamic participation of students. So, they have to draw up an academic work in groups and analyze practical cases based on real enterprises.

These activities have allowed students to acquire, besides the topics learning, abilities such as interdependence, responsibility, ability of information searching and oral communication.
The obtained results have been, in general, very satisfactory because academic works presented by students have been thorough and presentations have been enriching. Besides, students have positively considered the analysis of real enterprises and the academic work because they could find these questions in their professional work.

Nevertheless, there are various limitations derived from the increased work for professors as a consequence of the application of these methodologies and the persistence of a group of students that still consider, in a more positive way, the traditional methodologies where they adopt a more passive role.

\section{References}

[1] R.M. Rodríguez, "El resto de la convergencia: necesidades y cambios”, Revista de Formación e Innovación Educativa Universitaria, vol. 2, n² 2, 2009, pp. 154-164.

[2] European Commission, "The role of the Universities in the Europe of the Knowledge", Communication of the Commission of the European Communities. $n^{\circ}$ 5-02, 2003.

[3] J. González and R. Wagenaar (Ed.), Tuning Educational Structures in Europe, Universidad de Deusto, 2003.

[4] A. Barblan, The Sorbonne Declaration and implications: a personal view, Association of European Universities, Geneva, 1999.

[5] Ministros Europeos de Educación Superior, "El espacio europeo de educación superior-alcanzando las metas", Comunicado de la Conferencia de Ministros Europeos responsables de Educación Superior, Bergen, 2005.

[6] M.C. Van Der Wende, "The Bologna Declaration: enhancing the transparency and competitive of European”, Higher Education in Europe, vol. XXV, n 3, 2003, pp. 305310.

[7] D. Jonassen, F. Holland, R.M. Marra and D. Crismond, Meaningful learning with technology, Pearson: Upper Saddle River, 2008.

[8] MEC (Education Ministery of Spain), Borrador de propuesta de directrices para la elaboración de títulos universitarios de grado y master, Madrid, 2006.

[9] F. Michavila, "No sin los profesores", Revista de Educación, n 337, 2005, pp. 37-49.

[10] J. Calvo, "Enseñanza centrada en el desarrollo de estudiantes universiatrios", Revista de la Educación Superior, vol. XXXII, n 128, 2003.

[11] B. Martínez, J.N. García, P. Robledo, C. Díez, M.L. Álvarez, J.M. Marbán, A.M. De Caso, R. Hidalgo, O. Arias, D.I. Pacheco and C. Rodríguez (2008): "Valoración docente de las metodologías activas: un aspecto clave en el proceso de convergencia europea”, Aula Abierta, vol. 35, $\mathrm{n}^{\circ}$ 1-2, 2008, pp. 49-62. 
[12] M.A. Zabalza, Competencias docentes del profesorado universitario: calidad del desarrollo profesional, Ed. Narcea, Madrid, 2003.

[13] G. Brown and M. Bakthar, Styles oflecturing, ASTD Publication: Loughboroug University of Technology, 1983.

[14] Technical University of Madrid, El método del caso, http://innovacioneducativa.upm.es/guias/MdC-guia.pdf, (2008).

[15] M. De Miguel, Modalidades de enseñanza centradas en el desarrollo de competencias. Orientaciones para promover el cambio metodológico en el Espacio Europeo de Educación Superior, University of Oviedo, 2005.

[16] M.R. Zamora, "La aplicación de metodologías activas para la enseñanza de las ciencias jurídicas a estudiantes de primer curso", Revista Jurídica de Investigación e Innovación Educativa, nº 1, 2010, pp. 1-16. 